\title{
Polysèmes
}

Revue d'études intertextuelles et intermédiales

\section{The Dynamics of Confrontation and Connection in The Scarlet Letter: a Passage to America}

\section{Patricia Simonson}

\section{(2) OpenEdition}

\section{Journals}

Electronic version

URL: http://journals.openedition.org/polysemes/1603

DOI: 10.4000/polysemes. 1603

ISSN: 2496-4212

Publisher

SAIT

Printed version

Date of publication: 1 January 2003

Number of pages: 15-30

ISSN: 0999-4203

\section{Electronic reference}

Patricia Simonson, «The Dynamics of Confrontation and Connection in The Scarlet Letter: a Passage to America », Polysèmes [Online], 6 | 2003, Online since 10 January 2017, connection on 19 April 2019 URL : http://journals.openedition.org/polysemes/1603 ; DOI : 10.4000/polysemes.1603

This text was automatically generated on 19 April 2019

Polysèmes 


\title{
The Dynamics of Confrontation and Connection in The Scarlet Letter: a Passage to America
}

\author{
Patricia Simonson
}

1 The term "passages" applies to The Scarlet Letter in two rather different but closely related ways. On the one hand, the word can be applied to the novel's overall narrative structure in the sense of a voyage, a one-way progress from one world or from one state of being to another. At the same time, it can also be evoked in the sense of the Parisian passages which intrigued Aragon, ${ }^{1}$ as implying a coming and going between separate but connected spaces. The story unfolds according to a linear chronological sequence which takes the reader from the first scaffold scene (Chapters II-III), in which we see Hester being punished for her adultery, to the final scaffold scene (Chapter XXIII), in which Dimmesdale confesses his adultery and dies, apparently redeemed. The passage from the opening to the closing scene enacts a number of progressions which can be described as the characters', the narrator's, and the reader's respective journeys from this world to the next, from fact to fiction, from ignorance to knowledge; or at least, in these general directions. Nobody can be quite sure that any of the goals have been reached, because the tale's linear progression is the product of a far from linear structure. It evolves out of a dynamics of conflict and exchange metaphorically represented as Hester and Dimmesdale's persecution by the Puritan community, through the agency of the scarlet letter and its human representatives, Pearl and Chillingworth. This persecution is presented as the instrument of the protagonists' redemption, that is, their pilgrimage from sin to salvation: the movement from Hester's punishment to Dimmesdale's confession deliberately structures the text according to the general model of a Calvinist conversion story.

2 In the first part of this analysis I will examine this conversion story: we will see that it is far from orthodox. Hester's redemption never materializes in the text; and the minister's apparent apotheosis is very ambiguous. In the second and third parts of my analysis, I will 
discuss what lies behind this metaphorical conversion process: Hester and Dimmesdale's passage to the next world turns out to be in fact a passage to the New World. The text is showing us how a certain myth of America came into being; at the same time, it is constructing an open-ended dialectic between history and fiction which undermines the myth. ${ }^{2}$

\section{From this world to the next: The Scarlet Letter as a conversion story}

3 By a "conversion story" I mean a spiritual (auto-) biography in the tradition of St Augustine's Confessions, in which the writer recounts his passage from a state of sinfulness and religious indifference to a state of grace through repentance. This sort of literary production was widespread in the Protestant world throughout the seventeenth century. Two of the most famous Puritan examples were John Bunyan's account of his own conversion, Grace Abounding to the Chief of Sinners (1666), and his even more famous allegorical version of the same story: The Pilgrim's Progress from This World to That Which is to Come (1678). ${ }^{3}$

4 Hawthorne's narrative is structured according to this general model: it starts out with two sinners, Hester and Dimmesdale, and appears to be recording their progression through suffering and eventual repentance towards redemption. In both cases, the suffering is inflicted by a character who is presented as the providential instrument of the protagonists' salvation. Pearl's fascination with the scarlet letter makes the child her mother's persecutor; Hester interprets this as a providential "design of justice and retribution". ${ }^{4}$ Chillingworth starts out as Dimmesdale's self-designated persecutor; by the end of Chapter IX, he has become a "diabolical agent", but divinely authorized (like the Devil afflicting Job): "This diabolical agent had the Divine permission, for a season, to burrow into the clergyman's intimacy, and plot against his soul" (88).

5 Dimmesdale and Chillingworth's relationship reads as an explicit reference to The Pilgrim's Progress, because of Chillingworth's gradual transformation into an allegorical devil.

6 When this character first appears in the text, in Chapter III, he is described in relatively realistic terms: "small in stature, with a furrowed visage [...] a remarkable intelligence in his features [...] his heterogenous garb [...]" (43-44). By Chapter X, his eyes are gleaming with a "blue and ominous" light, explicitly compared to "those gleams of ghastly fire that darted from Bunyan's awful doorway in the hillside, and quivered on the pilgrim's face" (89). ${ }^{5}$ We will see that this transformation is taking place in the imagination and in the discourse of the characters themselves. This is an essential clue to just what sort of "conversion story" the two men's relationship is enacting.

7 Hester and Pearl's relationship does not constitute this sort of intertextual quotation. Nor does it lead to the characters' transformation into allegorical caricatures of themselves. This suggests that the two relationships (between Dimmesdale and Chillingworth, on the one hand, between Hester and Pearl, on the other) are enacting two very different passages.

8 We will start by examining Dimmesdale's experience. At first sight it seems to be the more orthodox of the two, since it ends with the sinner's repentance and apparent salvation. However, there is something rather odd about a conversion story in which the 
moment of conversion is also identified as the sinner's most serious fall, the psychological equivalent of a contract with the Devil. This is what we see happening to Dimmesdale in the famous forest interview with Hester, when she convinces him to run away with her. Chapter XVIII, "A Flood of Sunshine", reads as a parody of the pivotal scene in The Pilgrim's Progress, in which the hero, Christian, arrives at the foot of the Cross: there, his burden of earthly sin suddenly falls from his back and he goes on his way, assured of his future redemption, to confront the perils which still await him on his way to the City. ${ }^{6}$ This moment is Bunyan's allegorical representation of the specific psychological phenomenon which seventeenth-century Protestants called "conversion", that is, the moment in which the doubting individual's long introspection bore fruit in sudden conviction of grace. ${ }^{7}$

This is what seems to happen to the minister. Dimmesdale's decision to flee the Puritan community produces a state very much resembling the effects of a conversion experience. At least this is how the pastor himself describes it: "I seem to have flung myself-sick, sin-stained, and sorrow-blackened-down upon these forest-leaves, and to have risen up all made anew, and with new powers to glorify Him that hath been merciful!" (137). And yet, the narrator tells us very clearly in Chapter XVIII that this decision is a $\sin$ (136-137). And once the minister's state of euphoria wears off, on the way back from the forest, he is still describing his situation as a conversion experience, but this time a negative one: finding himself assailed by what he believes are diabolical temptations, he now decides that he may have sold his soul to the devil.

From this apparent fall Dimmesdale proceeds directly to his triumphant martyrdom on the scaffold, in Chapter XXIII. These two experiences would seem to be mutually exclusive, and one might suppose that in the interval a new conversion or transformation has taken place. However, this hypothetical event cannot be located in the text: there is no perceptible reversal between the character's "diabolical" conversion and his apparent redemption. Moreover, the narrator tells us something about the final scene which completely contradicts both the preacher's and Chillingworth's view of Dimmesdale's fate. We discover in the novel's conclusion that Chillingworth has accomplished his purpose in relation to his enemy: the minister's death on the scaffold of the pillory is described by the narrator as the "completest triumph and consummation" of the old physician's revenge (175).

11 So it seems that the preacher is damned after all. Of course, by the end of the paragraph, the text has once again contradicted itself: the opposite poles of redemption and damnation have collapsed into a benign, vaguely Transcendentalist "spiritual world" (175), in which the narrator imagines the supposed fiend and his victim meeting on friendly terms. The nineteenth-century narrator is drawing our attention to the fact that the seventeenth-century characters' redemption or damnation are essentially constructs formed by the characters themselves and by the Puritan community. The divine purposes which the characters claim to be obeying are in fact human purposes. In that case, just what are these purposes? 


\section{From the Old World to the New, or from history to allegory}

There are indications that Dimmesdale's passage from the forest to the scaffold, and from this world to the next, constitutes Hawthorne's metaphor for the entire community's passage to America, or rather, to a certain myth of America.

One major clue to what is going on is to be found in the event which links the forest scene with Dimmesdale's confession. I said that there was no perceptible break between these two scenes; there is, however, a perceptible connection: the writing and delivery of the preacher's final sermon. At the end of Chapter XX, we see him returning from the forest, transformed by his experience there. Whatever the exact nature of this transformation, it clearly provides Dimmesdale with the momentum for writing his sermon, since he arrives from the forest full of unaccustomed energy, throws away his first draft of the election sermon and immediately writes another in a sudden and unexpected burst of inspiration. The next day, he delivers his speech before the people of Boston; this act in turn seems to provide the impulse which leads to the final scaffold scene.

At the beginning of Chapter XXIII, the narrator gives us a brief summary of this final sermon:

[The minister's] subject, it appeared, had been the relation between the Deity and the communities of mankind, with a special reference to the New England which they were here planting in the wilderness. And, as he drew towards the close, a spirit as of prophecy had come upon him, constraining him to its purpose as mightily as the old prophets of Israel were constrained; only with this difference, that, whereas the Jewish seers had denounced judgments and ruin on their country, it was his mission to foretell a high and glorious destiny for the newly gathered people of the Lord. (168)

This passage is an intertextual minefield: phrases like "the New England which they were [...] planting in the wilderness", "the newly gathered people of the Lord" are indirect quotes from three generations of Puritan preachers and historians. Dimmesdale's sermon is in fact a deliberate reference to the entire process of historical self-definition undertaken by the New England Puritans; to a great extent, The Scarlet Letter is simultaneously recording this process, criticizing it, and proposing an alternative to it (this alternative is Hester's experience).

In The Puritan Origins of the American Self, Sacvan Bercovitch analyzes how the New England Puritans both expanded the individual conversion story into a model for their own "national" history, and appropriated for their own "local" uses the conversion story's universal allegorical meanings. ${ }^{8}$

The colonists saw themselves as escaping from the spiritual corruption of old England to establish the New Jerusalem in America. This led them both to formulate their concrete historical experience in allegorical terms and to give these allegorical terms a literal value: they identified the Old World as a kind of literal City of Destruction, and their New World as a literal Celestial City. The City of Destruction, symbolizing earthly corruption, is the starting-point for Christian's pilgrimage, in The Pilgrim's Progress, while the Celestial City is the heaven we see him entering at the end of his journey. Since both of these places symbolize spiritual states, their only legitimate connection to real geographical locations is metaphorical. But the sermons and chronicles produced by the seventeenth- 
century New England Puritans write the history of the colony in the form of a collective Pilgrim's Progress from the old World to the New: the voyage to America becomes in itself a form of redemption, the colonists are identified as the Lord's Chosen People, and New England becomes an earthly Kingdom of God.

The problem was that New England could not really be confused with the Kingdom of God, at least not for long; the colonists had to face physical and spiritual disasters, like famine or heresy. Fortunately, their problems could all be made to fit into the allegorical category of the Chosen People's persecution by the Devil. In the course of this process of self-identification, the locus of evil was displaced from Europe to the wilderness surrounding the Puritan settlements: the unexplored Indian territories functioned very well as a literal "dark forest of this life", against which Providence had to guard the Puritans' small-scale Celestial Cities. Moreover, any inhabitant of the settlements who did not conform to the official version of reality could simply be identified as diabolical, and evacuated into the Devil's territory outside. ${ }^{9}$ By the end of the seventeenth century, when the declining Massachusetts theocracy needed ever-more effective scapegoats, this opposition between the wilderness and the settlements had developed into an elaborate fiction, which may have contributed to the witchcraft hysteria of 1692. To a great extent it was the work of Cotton Mather, New England's most important preacher and historian at the time. In his accounts of the witchcraft trials, he explains the whole affair as the consequence of a conspiracy masterminded by the Devil against New England; the purpose of this conspiracy was to overthrow the Puritan theocracy by setting up a rival theocracy (or diabolocracy?) of Devil-worshippers, who were believed to hold reverse religious ceremonies in the forest and try to convert other Puritans. ${ }^{10}$ This "Great Conspiracy" of witches functioned in effect as a Gothic parody or mirror image of the Puritans' original New Jerusalem.

Dimmesdale and Chillingworth's relationship illustrates both stages of this allegorizing activity. From the beginning the preacher is defined by the Puritan community as an especially saintly figure, "little less than a heaven-ordained apostle" (83); Chillingworth materializes in the story as the direct consequence of this saint's transgression, and his persecution of the preacher coincides with his own transformation into a fiend. The witchcraft motif which recurs throughout the novel can be read in fact as a form of indirect discourse: it constitutes the reported speech of the Puritan community, and it shows us this community in the process of substituting two-dimensional representations for the complex individual realities of its members. This is the process that lies behind the metaphor of diabolical conversion evoked in the forest scene. If we look at the passage more closely, we will see that something resembling a Devil's contract actually does take place: that is, the protagonists' revolt against Puritan law does not lead them out of the Puritan allegorical universe. It simply seduces them into adopting the ultimate allegorical identity in the Puritan system: the role of the scapegoat.

At least this is what happens to Dimmesdale. Hester's rather different experience could be described as a failed conversion; this fortunate failure seems to be Hawthorne's metaphor for his own dialectic fiction.

\section{From history to allegory and back again}

The whole forest episode lasts from Chapter XVI to Chapter XX. In Chapter XVI, we see Hester and Pearl entering the forest, where Hester hopes to intercept Dimmesdale on his 
way back from a visit to a fellow minister, in order to speak with him privately. Chapter XVII describes the first part of Hester and Dimmesdale's conversation: Hester confesses to Dimmesdale that Chillingworth is her husband, and proposes that she and the minister and Pearl flee the Puritan settlement together. After some resistance, Dimmesdale consents. This decision, and its immediate effects, are described in Chapter XVIII: this is the passage we described earlier as the "conversion scene". Unlike Dimmesdale, Hester is not radically transformed by this experience: she remains essentially the same before and after the forest episode. A closer look at the text will help us understand just what has happened to each of the two characters.

The central passage has often been taken for Hawthorne's Romantic benediction on his rebellious lovers: once they decide to flee together, Hester takes off the letter, lets down her hair, and is miraculously transfigured into a beautiful, prelapsarian Eve in the midst of an innocent, sympathizing wilderness called "Nature" (137-38). However, this Romantic wilderness is not a Romantic wilderness. It is very much a Puritan construct, and provides the setting for some characteristically Puritan behavior.

We have already had a hint, in Chapter XVI, that to enter the forest is to enter the Puritan imagination itself. At the beginning of the chapter, Pearl mentions the "Black Man", that is, the Devil in Puritan superstition. The child draws our attention to the fact that she and her mother are entering his territory. Or rather, she draws our attention to the fact that Puritan belief identifies the forest as the Devil's territory. She does not simply tell us about the Black Man; she tells us a story which she has heard about him from an "old dame in [a] chimney-corner" (126). In Hawthorne's fiction, old women in chimney corners are the traditional sources of fantastic stories, the guardians of the community's imaginative resources.

Later on, in Chapter XVIII, another essential passage again identifies the landscape as a Puritan creation. The very phrase which seemed the most unmistakably Romantic is an intertextual trap: it conceals a characteristic piece of Puritan historiography treacherously embedded in the Romantic lyricism. As the two lovers appear to liberate themselves from the fetters of Calvinist morality, we see the forest suddenly flooded with sunlight: "Such was the sympathy of Nature-that wild, heathen Nature of the forest, never subjugated by human law, nor illumined by higher truth-with the bliss of these two spirits!" (138). To the unwary reader, this sounds like the narrator speaking. But the narrator has already provided us with historical information that directly contradicts this sentence. We learn at the beginning of Chapter XVI that the minister has gone to visit "the Apostle Eliot, among his Indian converts" (124). The Apostle Eliot was the famous John Eliot, a Puritan missionary to the Massachusetts Indians; by the middle of the seventeenth century he had established fourteen communities of converted Indians in the wilderness. So even in Puritan terms the phrase "never illumined by higher truth" is incorrect (we can assume in this context that "higher truth" means Christianity). Moreover, the reference to "heathen Nature", and the equation between the landscape's "heathen" character and the assumed absence of human life, is typical of seventeenthcentury Puritan discourse. There were human beings and human laws in the wilderness: it was full of Indians. But the ordinary colonist did not consider Indians as human beings; Hawthorne's sentence is presenting in condensed form all the essential arguments by which these "ordinary" Puritans justified the colonization process. So this "wild, heathen Nature of the forest" is in fact a Puritan fabrication, intruding into the midst of the two lovers' Romantic Nature. And the protagonists' behavior in this 
passage is equally ambivalent. In the very act of apparently freeing themselves from the Puritan system, they are actually doing something typically Puritan: confusing the symbolic and the literal. As Hester takes off the letter, she declares: "With this symbol, I undo it all, and make it as [if] it had never been" (137). This is a very suspicious statement: up until now, the letter has been treated virtually as a part of Hester's body. The use of the word "stigma" to describe the letter is particularly ironic: "The stigma gone, Hester heaved a long, deep sigh [...]" (138). The term originally meant the scar from a hot iron, something which by definition cannot be removed; and the letter has indeed been compared on various occasions to a brand. Hester herself has said that it cannot be taken off: it will fall off of itself (like Christian's burden) the day she no longer deserves to wear it (115). But it has not fallen off; she has taken it off after all, and is behaving as if this symbolic gesture really "undid" something which was committed, not symbolically, but in actual fact. Like the Puritan community itself, Hester is creating for herself a simplified identity; ironically, this identity is just as much an allegorical caricature as the previous one. Her gesture and words as she removes the letter aim at a deliberately magical effect. Hester is adopting the role of the witch: this is indeed her conversion to the Puritan allegory.

But the narrator will save her, through the agency of Pearl. Pearl's behavior in Chapter XVIII constitutes a condemnation of what has just occurred between the two adults (not surprisingly, since Hester's magical gesture has presumably "undone" the child by undoing the act of her conception); Pearl's anger finally forces Hester to reverse her action and take up the letter again. This chapter can be read as Hawthorne's commentary on the ideal relationship between reality and its representation. The whole passage describing the confrontation between Hester and the child is marked by the narrator's curious emphasis on the presence of the brook, and on the child's reflection in the water. It is not only Pearl who confronts Hester: it is Pearl and her image, "another child,-... and the same" (141-143). At every stage of the interview, the text reminds us that the reality and its image, or the symbol and what it represents, are a total entity, of which neither part can be divided from the other.

And yet this is what seems to have happened to Dimmesdale when he returns to the Puritan settlement. The narrator imagines him describing his new state to his friends:

I am not the man for whom you take me! I left him yonder in the forest, withdrawn into a secret dell, by a mossy tree-trunk, and near a melancholy brook! Go, seek your minister, and see if his emaciated figure, his thin cheek, his white, heavy, pain-wrinkled brow, be not flung down there like a cast-off garment! (147)

Or like an embroidered letter: Dimmesdale has left his guilty self in the forest, as Hester tried to leave hers. The simplified identity which remains to the minister is even more faithful than before to the dominant allegory. When he finds himself assailed by strange impulses on his return from the forest, his reaction is in perfect conformity with Puritan superstitions: "[...] am I given over entirely to the fiend? Did I make a contract with him in the forest, and sign it with my blood?" he asks himself (149). This is a new development: throughout the novel, the minister has been obsessed with his own guilt; now he is attributing it to the Puritan community's favorite scapegoat, the Devil. And his attitude to the forest has also undergone a curious change: "The pathway among the woods seemed wilder, more uncouth [...], and less trodden by the foot of man, than he remembered it on his outward journey" (146). The forest as he now perceives it is closer to the Puritan fiction of the empty wilderness which we mentioned earlier. This transformation culminates in the final scaffold scene, in which Dimmesdale's confession 
of adultery represents a mirror image of his previous saintly identity; like the Devil's conspiracy, its function is to provide the community with a scapegoat enabling it to preserve at least the illusion of its own purity. "People of New England!" declares the preacher, "[...] ye, that have deemed me holy!- behold me here, the one sinner of the world!" (172).

Throughout the novel, Hawthorne is busy preventing this dissociation between reality and allegory from happening to his text: that is, he is making sure that both the historical facts and the historical fictions remain visible, neither one destroying or assimilating the other. This confrontational dialogue between history and fiction can also be described as the author's persecution of the poor reader, who is obliged to find his or her way through a labyrinth of deliberate omissions, anachronisms, and inaccuracies (always detectable, but not always easily)-persecuting the text in his turn, in order to make it produce solutions to its mysteries. Unlike Chillingworth and Dimmesdale's relationship, but perhaps, like Hester's connection to the letter, this confrontation never comes to an end. ${ }^{11}$ The final chapter, instead of bringing it to a close, merely opens new perspectives, in the future suggested behind Dimmesdale's apotheosis. The final scaffold scene is deliberately dated by the intrusion (in Chapter XII) of a historical event, the death of Governor Winthrop, the first governor of Massachussetts. Dimmesdale delivers his final sermon, a shamelessly nationalistic discourse prophesying a glorious future for New England, in honor of Winthrop's successor, whose inauguration we see in the final chapters. But the glorious future predicted by the minister is seriously undercut by the identity of this new Governor. The narrator deliberately omits his name, but the historical clues in the text allow the inquiring reader to find out that Winthrop's successor is John Endicott, one of the most intolerant among the Puritan leaders, a man whose government will be tainted by acts of bloody persecution.

In The Rites of Assent, Bercovitch analyzes The Scarlet Letter as the gradual socialization of Hester Prynne (interpreted as a figure of the artist), and her reconciliation with a society with which she was originally in conflict. ${ }^{12}$ Bercovitch's reading is very impressive and mostly very convincing; but I cannot agree with him as to the final reconciliation: whatever the heroine's situation may be at the end of the novel, at another level a confrontation is still going on. The artist does not seem to be reconciled to his society-at least, not to the extent of believing, or letting the conscientious reader believe, this society's stories about itself.

\section{BIBLIOGRAPHY}

Arac, J. "The Politics of The Scarlet Letter", in S. Bercovitch and M. Jehlen (eds). Ideology and Classic American Literature. Cambridge: Cambridge UP, 1986.

Bell, M. D. Hawthorne and the Historical Romance of New England. Princeton, NJ: Princeton UP, 1971.

Bercovitch, S. The Office of the Scarlet Letter. Baltimore and London: Johns Hopkins UP, 1991.

Bercovitch, S. The Puritan Origins of the American Self. New Haven, CT: Yale UP, 1975. 
Bercovitch, S. The Rites of Assent. New York: Routledge, Chapman and Hall, 1993.

Berlant, L. The Anatomy of National Fantasy. Chicago: The U of Chicago P, 1991.

Bunyan, J. Grace Abounding to the Chief of Sinners. 1666. London: Penguin Books, 1987.

Bunyan, J. The Pilgrim's Progress from this World to that which is to come. 1678. London: Gibbins and Company Limited; Philadelphia: J.B.Lippincott, 1902.

Colacurcio, M. The Province of Piety. Cambridge, MA: Harvard UO, 1984.

Dekker, G. The American Historical Romance. Cambridge: Cambridge UP, 1987.

Hawthorne, N. The Scarlet Letter. 1850. Columbus (Ohio): Ohio University State Press (The Centenary Edition, Vol.1), 1962.

Mather, C. Wonders of the Invisible World. 1692. Nn G. Burr, ed. Narratives of the Witchcraft Cases, 1648-1706. New York: Barnes and Noble Inc., 1975.

Miller, P. The New England Mind: The Seventeenth Century. New York: The Macmillan Company, 1939.

Shea, D. B. Spiritual Autobiography in Early America. Madison, WN: The U of Wisconsin P, 1988.

\section{NOTES}

1. Louis Aragon, Le Paysan de Paris (Paris, 1926).

2. My remarks in this essay are indebted in many ways to a number of other critics who have discussed the potentially subversive nature of Hawthorne's historical fiction: see mainly Michael Davitt Bell, Hawthorne and the Historical Romance of New England (Princeton, NJ: Princeton University Press, 1971); Michael Colacurcio, The Province of Piety (Cambridge, MA: Harvard University Press, 1984); Jonathan Arac, "The Politics of The Scarlet Letter", in Sacvan Bercovitch and Myra Jehlen, eds, Ideology and Classic American Literature (Cambridge: Cambridge University Press, 1986); George Dekker, The American Historical Romance (Cambridge: Cambridge University Press, 1987); Lauren Berlant, The Anatomy of National Fantasy (Chicago: The University of Chicago Press, 1991); Sacvan Bercovitch, The Office of the Scarlet Letter (Baltimore: Johns Hopkins University Press, 1991), and "The Return of Hester Prynne", in The Rites of Assent (New York: Routledge, Chapman and Hall, 1993). Among these authors, Bercovitch and Arac are the most inclined to conclude that Hawthorne actually upholds mainstream American myths of identity.

3. One of the classic discussions of the American forms of the spiritual autobiography is Daniel B. Shea's Spiritual Autobiography in Early America (Madison, Wisconsin: The University of Wisconsin Press, 1988).

4. Nathaniel Hawthorne, The Scarlet Letter (New York, W.W. Norton \& Company, 1988), 123. From now on page numbers will be given in parentheses in the text.

5. See John Bunyan, The Pilgrim's Progress (London: Gibbings and Company, Ltd., 1902), 194. This doorway, which is shown to Christian and his fellow-pilgrim Hopeful by the shepherds of the Delectable Mountains, is "a by-way to hell", reserved for hypocrites, who are seized by the devils just as they think they are on the point of entering the Celestial City. This prefigures the ambiguity of Dimmesdale's supposed salvation at the end of The Scarlet Letter.

6. Bunyan, op. cit., 53-54.

7. For an account of this process, see Perry Miller, The New England Mind: The Seventeenth Century (New York: The Macmillan Company, 1939).

8. Bercovitch, The Puritan Origins of the American Self (New Haven, CT: Yale University Press, 1975). 
9. Today, we notice that this psychological phenomenon persists largely unchanged, though the geographical location of the Devil's territory has shifted somewhat.

10. See Cotton Mather, Wonders of the Invisible World (1692), in Burr, George, ed., Narratives of the Witchcraft Cases, 1648-1706 (New York: Barnes and Noble, Inc., 1975).

11. Hester has been interpreted as a figure of the author; but she can also be seen as a figure of the reader, who stands in a similar relation to the letter, that is, to the text.

12. See Bercovitch, "The Return of Hester Prynne", in The Rites of Assent.

INDEX

oeuvrecitee Scarlet Letter (The) 